\title{
Evaluation of the Impact of Brand Purchase Involvement, Satisfaction, Experience and Brand Trust on Loyalty to Brand
}

\author{
Hossein Vazifehdoost \\ Department of Business Management, Science and Research Branch, Islamic Azad University, Tehran, Iran \\ Afshin Rahnama \\ Department of Business Management, Science and Research Branch, Islamic Azad University, Tehran, Iran \\ *Corresponding author. Email: Afshin.rahnama@yahoo.com \\ Seyed Javad Mousavian \\ Department of Business Management, Rasht Branch, Islamic Azad University, Rasht, Iran
}

Doi:10.5901/mjss.2014.v5n20p3054

\begin{abstract}
Brand is not only a name but it is a representative of a product class. Sometimes, a product's name is embedded in consumers' minds so firmly that consumers forget it is only a name and view it as equal to a product and service. Brands are considered as being very important in market. They are joints between consumers and companies. Loyalty to a brand is created when a customer believes that a brand reflects some aspects of his or her perception. If a brand establishes symbolic relationship with customers, they will be attracted to the brand and trust in the brand and become loyal to it. They will buy the product and believe in its supremacy. The present research tries to investigate the impacts of brand experience on satisfaction with brand and brand experience on trust in brand and in general, it investigates the impacts of brand purchase involvement, brand trust, satisfaction with brand and brand experience on loyalty to brand. The present research is a descriptive study and simple random sampling method was used to pick sample members. 282 questionnaires were collected. Structural equations modeling method was used to analyze data. PLS software was used for analysis because data distribution was not normal. Results showed that brand experience has direct influence on satisfaction with brand, trust in brand and loyalty to brand. Further, satisfaction with brand, trust in brand, pleasure with brand purchase and brand symbolic value have direct impacts on loyalty to brand.
\end{abstract}

Keywords: loyalty to brand, pleasure with brand purchase, symbolic brand value, brand experience, trust in brand and satisfaction with brand

\section{Introduction}

In any company, whether a service or a production one, the most important factor in conservation is customer. If an organization cannot satisfy its customers and cannot make them loyal, it will not achieve long-term growth (Rahnama et al, 2012). Today, brand is the main capital of many organizations. For years, a company's value was evaluated by its properties, tangible assets, factories and equipment. However, real value of a company is placed somewhere in customers' minds (Kapferer, 2006). We can dare say the most important professional skill of marketers is their capability to create, maintain, care for and promote a brand. Marketers believe that: brand creation is the art and base of marketing (Kotler, 2006). It must be noted that loyal customers bring many advantages. these include improvement of profitability, reduction in marketing costs, increase in corporate sales, customers with low price sensitivity and so on (Rahnama et al, 2012). Loyalty to brand is a fundamental concept in strategic marketing. Companies design marketing strategies in order to increase loyalty to brand so that they can maintain their market share and achieve higher profitability. Loyalty to brand also can lead to other advantages like word-of-mouth marketing and competitive advantage (Datta, 2003). It has also several strategic benefits like acquisition of larger market share, new customers, support for brand development, reduction in marketing costs and brand improvement against competitors' threats (Atilgan et al, 2005). Kapferer and Larent (1985) investigated product purchase involvement as a multi-dimensional concept and identified 5 factors. These include: "pleasure with purchase, tendency to purchase, risk possibility, sign value, risk importance" (Kapferer and 
Laurent, 1985). The present research also tries to investigate relationship between product purchase involvement and loyalty to brand. This study has contribution to product purchase involvement concept. Therefore, in order to present a good image of consumers which are more likely to get involved in product purchase, it is necessary to determine factors which affect consumer's involvement. The main question of the research is: "how is the impact of brand purchase involvement, satisfaction with brand, trust in brand and brand experience on loyalty to brand?" brand experience is very important for marketers. Brand experience is described as feelings, perceptions and behavioral responses which are created by brand-related stimulants. These stimulants are parts of brand design and identity, classification, communications and conditions. Brand experience influences satisfaction, trust and loyalty. From a customer's viewpoint, brands establish links. In the present research, we investigate the impact of brand experience on establishment of longterm relationship with customers, satisfaction with brand and loyalty to brand.

\section{Theoretical background}

\subsection{Loyalty to brand}

As Stephen King says, a product is something which is produced in a factory: a brand is what a customer purchases. A product may be copied by a competitor but a brand is something unique. A product has a short lifecycle but a successful brand stays for long. American Marketing Association defines brand as:

A brand is a commercial name, phrase, sign or a combination of them which is used to differentiate a company's product or service from competitors. For short, brand helps identify a seller or manufacturer. A brand is a permanent commitment of a seller to provide a collection of characteristics, advantages and special services. Commercial name theory changed into brand over years. In the early days of emergence of this concept, products were named and naming included a sign which was characterized as a sign or symbol of product ownership (Coomber, 2003). A brand is an abstract of identity, originality, characteristic and difference with competitor products. Brand is not only a name but it is a representative of a product class. A brand is an important guide for a potential customer. Like money, brand facilitates a transaction. Customers are not sure about a collection of products which cannot be evaluated. Brands and prices facilitate understanding of products (Kapferer, 2006). Wang (2004) believes that increase in comprehensive awareness of customers about market, access to information, diversity of products and other factors have caused customers not to be very loyal to organizations. Therefore, customers' loyalty is an important element in organizational profitability and growth. Loyal customers bring competitive advantages for organizations. Loyalty to brand can be defined as:

The level to which a customer has a positive attitude to a brand, his or her commitment to the brand and intention to repeat purchase (Mowen and Minor, 2009). This definition emphasizes on two different dimensions of loyalty i.e. behavioral dimension and attitudinal dimension. Behavioral loyalty involves repeating purchase several times and attitudinal loyalty concerns commitment to value which is accompanied by a brand (Chaudhuri and Holbrook, 2002).

\subsection{Behavioral approach to loyalty to brand}

Bown (2001) believes that behavioral dimension refers to re-purchase and preferring a brand or service to another (Asgarpour, 2007, 89). Dabehkara (1999) believes that attitudinal approaches cannot be used for understanding low-risk brand purchase or when random purchase or customer's diversity search is considered (contrary to important or high-risk decisions) (Uncle \& et al, 2003). Behavioral approach to brand loyalty evaluates real behavior of customers towards a product. Proportion- of- Purchases Method is the most applicable criterion of brand loyalty. In this approach, all special product purchased brands for each consumer is determined and ratio of each brand is identified. Then, brand loyalty is measured in terms of an arbitrary proportion of a particular brand. For instance, if more than $50 \%$ of purchases over a time period goes to a particular brand, we call that customer loyal to that brand (Mowen and Minor, 2009). Every company seeks for having brands to which many customers are loyal. Unfortunately, not all brands manage to attract high loyalty.

Loyalty to brand is a consumer's preference for buying a unit brand among a collection of competitor brands. Brand loyalty is the result of brand perceived quality and not its price.

As Oliver (1997) defined, loyalty is a deep commitment for rejecting or encouraging preferred services or products in future (Chaudhuri and Holbrook, 2001). 


\subsection{Attitudinal approach to loyalty to brand}

Since there are some problems with behavioral approach to brand, differentiation between brand loyalty and repeated purchase is important. Repeated purchase behavior takes place when a customer purchases products repetitively and without having any special sense about it. In contrast, brand loyalty emphasizes on real preference of a brand. Therefore, another approach to brand loyalty has been developed. This approach is based on attitude towards a product and purchase behavior (Mowen and Minor, 2009).

\subsection{Brand purchase involvement concept}

when it comes to the historical background of involvement, it must be said that conceptualization of mental involvement of consumers is largely indebted to social psychology. The origin of studies conducted on involvement concept can be attributed to social judgment theory which was propounded by Sherif et al (1965), Sherif and Cantril (1947) and Sherif and Holend (1961). This theory deals with way of thinking, organizing thought, behavior change processes and judgment (Laaksonen, 1997). Involvement is a psychological construct which was introduced by Cantril and Sherif (1947). They believe that involvement is a state which occurs to an individual when conscious and semi-conscious stimulants affect the individual. They believed that individuals can have different types of involvement. For instance, involvement in activities, objects, beliefs, social issues and so on. Therefore, a person can also be involved in a product. Mac William (1997) believes that involvement includes perceived risk (financial, physical, socio-psychological or time-related risk), selfexpression (usually refers to self-concept), perceived importance and hedonistic value. Therefore, involvement should be studied as a multi-dimensional structure and it is not acceptable to view it as a one-dimensional factor. Understanding of dimensions of involvement is essential to creating a dynamic image of consumers' mental conditions. This is verified by the concept of consumer's mental involvement profile (CIP) which was propounded by Kapferer and Laurent.

\subsection{Involvement dimensions}

\subsubsection{Purchase pleasure}

According to CIP (Kapferer and Laurent, 1985), purchase pleasure is one of the five dimensions which can be used for explaining consumer purchase involvement in a product. They defined this factor as a value based on product purchase, emotional appeal and a product's ability to provide pleasure for an individual (Heidarzadeh \& Khoshpanjeh, Rahnama, 2011). Chadori and Hol Broke (2002) considered emotions and feelings of pleasure as important elements in purchase decisions and presented an explanation for this phenomenon. They proposed that products are on a spectrum from profitmaking (benefit-based products) to pleasing (pleasure-based products). They believe that hedonism results in commitment and loyalty to brand(Heidarzadeh, Khoshpanjeh\&Rahnama, 2011).

\subsubsection{Sign value}

A product's symbol is an important element when searching for a product or service. This means that people sometimes buy some products in order to indicate some meanings and notions about them. For instance, some indiivduals take cosmetic surgical operation to attach aearrings to their ears or noses or tattoo an image on their bodies so that they can show others that who they are and what they do (Mowen and Minor, 2009). Some products have importance beyond their function. This importance is resulted from products abilities for presenting meaning. Helman (1981) and Salomon (1983) state that products are symbols by which individuals can transfer something to others. Levi (1959) believes that: all commercial products have symbolic nature and. Studies showed that this symbolic meaning impacts on consumer's preferences (Heidarzadeh\&Khoshpanjeh and Rahnama, 2011). Kapferer and Laurent (1985) believed that sign value is the very symbolic value which is attributed to a product by a consumer. In other words, this concept shows that to what level a consumer uses a product for self-concept description and personal values (Quester \& Lim, 2003). Christianson et al (1999) considers sign value as an important dimension of product purchase involvement. They believed that this concept is one of the factors which can be used for better description of relationship between a consumer and product (Bin Esmail et al, 2006). 


\subsubsection{Brand experience}

This concept was first introduced by Smith (1997). Brand experience is originated from a collection of tendencies between a customer and a brand, a company or a part of an organization (Schmitt, 2009). In marketing literature, experience concept has been studied in fields like purchase experience, product experience, beauty experience, serving experience and consumer's experience (DehghaniSoltani et al, 2013). Brand experience refers to internal response (sentimental, emotional and cognitive) of a consumer and also his or her behavioral response to brand stimulants (Zarantolleno\&Schmit, 2010). Satisfaction is a positive emotional response resulted from previous experiences. Customers' satisfaction is the result of experience of a product or service by a brand and it is affected by performance and features of a product or service. In fact, brand experience has a positive and significant impact on brand satisfaction (Motaharinejad et al, 2014). Walter et al (2013) also verifies the positive relationship between brand experience and satisfaction (Walter et al, 2013). A large volume of a brand experience forms when an individual is exposed to the marketing mix strategy of that brand (Shamim\& Butt, 2013).

\subsubsection{Trust in brand}

Trust is a factor which differentiates between relationships and transactions. Any kind of individual relationship between an individual and brand is based upon trust. Trust acts like a bridge between satisfaction and individual relationships and directs positive transaction towards close relationships between brands and individuals (Hess \& Story, 2005). Trust reflects certainty, honesty and ability in relationship between a brand and a consumer which is attributed to a brand by consumers (Ashley \& Leonard, 2009). Trust in brand has two dimensions: 1. Cognitive dimension: which indicates technical nature and is based upon competency. This dimension indicates that to what level a brand can fulfill its commitments and satisfies consumers' needs. 2. Emotional dimension: it is originated from consumers' perceptions of a brand's goodwill in relationship between benefits and welfare of consumers (Sahin et al, 2011). Considering the previous studies, brand trust can be considered as an important factorin customer's loyalty. Level of trust consumers have in a brand influences their decisions about their purchase (Dehghani, Soltani et al, 2013).

\subsubsection{Satisfaction with brand}

In formulation of customers' strategy, customer's loyaltyis of strategic importance. Customers' loyalty is a common subject among managers and advisors amd academicians (Haghighi et al, 2012). Satisfaction is a positive response and is resulted from an expectable experience. Before a new purchase, customers compare their expectations with previous experience (BameniMOghaddam et al, 2011). A customer's satisfaction with a brand is the outcome of a consumer's psychological perceptions, evaluations and responses at the time of experiencing a product or service. Benefits of customer's satisfaction include increase in transactions, tendency to increase purchases, reduction in prices and transactions costs (Mc Calling \& O Sullivan, 2012).

\section{Research conceptual model}

An investigation of research literature on identification of factors affecting loyalty reveals that an increase in mental involvement in a product can result in loyalty to a particular brand. Consumers which have more involvement and interaction with a particular brand are more committed to that brand and therefore are more loyal to that brand. In this study, we used Kapferer and Laurent's studies (1985) and their multi-dimensional structure for product purchase involvement as a base for our hypotheses. Further, Shahin, Zehir\&Ketabchi (2011) investigated the impact of dimensions of brand on loyalty to brand. In the present research, we used two dimensions of Kapferer and Laurent (1985) CIP scale: pleasure with purchase and sign value. Furthermore, we investigated three dimensions proposed by Shahin et al, 2011: satisfaction with brand, brand experience and trust in brand. Finally, we used the two previous studies to develop research model and hypotheses. 


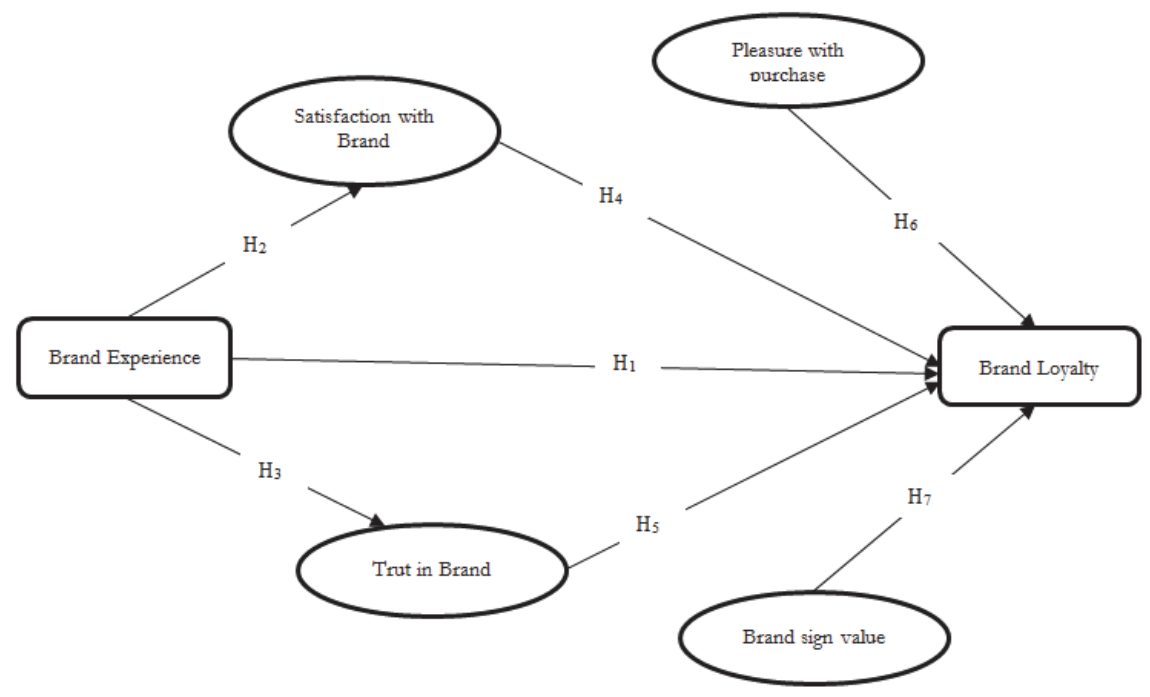

Figure 1. Conceptual research model

\section{Research hypotheses}

$\mathrm{H1}$ : brand experience has a direct impact on brand loyalty.

$\mathrm{H} 2$ : brand experience has a direct impact on satisfaction with brand.

H3: brand experience has a direct impact on trust in brand.

H4: satisfaction with brand has a direct impact on brand loyalty.

H5: trust in brand has a direct impact on brand loyalty.

H6: pleasure with brand purchase has a direct impact on brand loyalty.

$\mathrm{H} 7$ : brand sign value has a direct impact on brand loyalty.

\section{Research methodology}

This research tries to investigate factors which affect loyalty to Apple Mobile Phones brand in Tehran City. It is an applied study in terms of its target. In terms of data collection, it is a descriptive study. Further, the research is a correlation study and makes use of structural equations modeling method.

\subsection{Statistical sample and population}

Statistical population of this research is all Tehran City residents who have Apple Cellphones or had Apple Cellphones before. Because population size was unlimited, the following equation was used to determine sample size:

$$
n=\frac{Z_{\alpha / 2}^{2} \times P(1-P)}{\varepsilon^{2}} \quad n=\frac{(1.96)^{2} \times 0.5 \times 0.5}{(0.06)^{2}}=\mathbf{2 6 7}
$$

$\mathrm{Z}$ is standard normal probability, alpha is error level, $\mathrm{P}$ is success ratio and Epsilon is the expected exactness (Momeni, Fa'alGhayyoumi, 2005). In this research, certainty level was $95 \%$ and exactness was $6 \%$. Considering the fact that there was no estimation about success ratio, it was assumed to be equal to 0.5 and sample size in this state is increased to its maximum allowable level. 


\subsection{Data collection instrument}

In order to acquire data, a questionnaire was used. All questions had a five-point Likert scale from "completely disagree" to "completely agree". After preparation of the questionnaire, 30 questionnaires were distributed among population members as a pretest and for testing its reliability. Results showed that Cronbach's alpha coefficient is 0.7 for total questionnaire (alpha coefficients are summarized in table 1 for all variables). On the other hand, content validity of the questionnaire was verified by experts. Therefore, it can be said that the questionnaire is of acceptable validity and reliability.

Table 1. Cronbach's alpha coefficient

\begin{tabular}{|c|c|c|}
\hline Calculated Cronbach's alpha & questions & Research variables \\
\hline 0.727 & $1-4$ & Brand experience \\
\hline 0.714 & $5-7$ & Satisfaction with brand \\
\hline 0.767 & $8-10$ & Trust in brand \\
\hline 0729 & $11-14$ & Pleasure with brand purchase \\
\hline 0.712 & $15-19$ & Brand sign value \\
\hline 0.847 & $20-25$ & Loyalty to brand \\
\hline 0.80 & $1-25$ & Total questionnaire \\
\hline
\end{tabular}

Considering the needed sample size and because there are always some defective questionnaires, we distributed 350 questionnaires among sample members. In order to collect data, we distributed the questionnaires among customers who referred to Iranian Passage and Iranian Mobile Market which are the main cellphone centers in Tehran City. The questionnaires were randomly distributed among sample members over three weeks. 282 usable questionnaires were returned. Therefore, questionnaires return rate was 81\%. Table 2 depicts demographic information of the respondnets.

Table 2. research demographic variables

\begin{tabular}{|c|c|c|c|}
\hline variable & dimensions & frequency & Frequency percentage \\
\hline \multirow{3}{*}{ gender } & male & 188 & 0.667 \\
\cline { 2 - 4 } & female & 94 & 0.333 \\
\hline \multirow{4}{*}{ age } & $21-30$ & 128 & 0.454 \\
\cline { 2 - 4 } & $31-40$ & 89 & 0.316 \\
\cline { 2 - 4 } & $41-50$ & 46 & 0.163 \\
\cline { 2 - 4 } & 51 and above & 19 & 0.067 \\
\hline \multirow{3}{*}{ education } & High school & 62 & 0.220 \\
\cline { 2 - 4 } & Associate's degree & 49 & 0.174 \\
\cline { 2 - 4 } & bachelor & 114 & 0.404 \\
\cline { 2 - 4 } & Master degree and above & 57 & 0.202 \\
\hline
\end{tabular}

\section{Data Analysis and Hypotheses Test}

\subsection{Investigation of normality of variables}

In order to investigate research variables, we used Kolmogrov-Smearnov test for determination of normality of the variables. Results of Kolmogrov-Smearnov test have been summarized in table 3. 
Table 3. Kolmogrov-Smearnov test for research variables

\begin{tabular}{|c|c|c|c|c|c|c|}
\hline & $\begin{array}{l}\text { Perceived } \\
\text { relative } \\
\text { advantage }\end{array}$ & $\begin{array}{l}\text { Perceived } \\
\text { ease }\end{array}$ & $\begin{array}{c}\text { Perceived } \\
\text { compatibility }\end{array}$ & $\begin{array}{l}\text { Perceived } \\
\text { competency }\end{array}$ & $\begin{array}{c}\text { Perceived } \\
\text { goodwill }\end{array}$ & $\begin{array}{c}\text { Perceived } \\
\text { integrity }\end{array}$ \\
\hline $\mathbf{N}$ & 282 & 282 & 282 & 282 & 282 & 282 \\
\hline Normal & 3.6241 & 3.6738 & 3.6336 & 3.6253 & 3.6746 & 3.6144 \\
\hline Parameters ${ }^{a, b}$ & .49509 & .52153 & .55079 & .62965 & .52546 & .60800 \\
\hline Most Fxtreme & .099 & .179 & .146 & .088 & .139 & .138 \\
\hline Most Extreme & .099 & .179 & .146 & .088 & .113 & .121 \\
\hline गIterences Negative & -.079 & -.147 & -.130 & -.086 & -.139 & -.138 \\
\hline Kolmogorov-Smirnov Z & 1.659 & 3.009 & 2.456 & 1.477 & 2.327 & 2.316 \\
\hline Asymp. Sig. (2-tailed) & .008 & .000 & .000 & .025 & .000 & .000 \\
\hline
\end{tabular}

As it can be seen in table above, all significance numbers for research variables were smaller than 0.05 . this means that research data have non-normal distribution.

\section{Research hypotheses test}

Considering the fact that the present model measures relationships among several latent variables simultaneously, we used structural equations modeling method. This method is a statistical method which embraces other techniques like multivariate regression, factor analysis, path analysis and its main concentration is on latent variables which are defined by measurable and observable variables. Since the assumption of normality of the variables distribution is not verified, we used PLC (which is a variance-oriented path modeling technique) for testing the conceptual model of the research and this enables us to investigate the theory and variables simultaneously (Frennel and Locker, 1981). Contrary to covariance-oriented methods, this methid can be used for small size samples and also for the cases in which variables distributions are not normal (Azar et al, 2012). Data analyses calculations and hypotheses test was conducted by Smart PLS software.

\subsection{Outer model}

In PLS models, two types of models are tested. The outer model is the equivalent of measurement model and inner model is the equivalent of structural model in structural equations modeling method. Inner model indicates factor loadings of the observed ariables.

In outer model, internal consisitency of the model or reliability of the model is measured by calculating composite reliability (PC). If all model structures want to have high composite reliability, all values calculated for composite reliability coefficients must be above 0.6 (Bogezi and Yi, 1988). Coefficients of composite reliability have been listed in table 4 . As it can be seen, all values are above 0.6 and the model has therefore an acceptable internal consistency.

In order to investigate convergent validity, we used average variance extracted index (AVE) (Azar et al, 2012: 162). Convergent validity means all variables and items describe the main construct. To put it more easily, each index only measures its own construct and all constructs are separated from each other. Results of AVE have been listed in table 4. Results show that all studied constructs have AVE values above standard value (0.5) (Frenel and Locker, 1981). 
Table 4. outer model of the research and AVE and $P_{c}$ coefficients

\begin{tabular}{|c|c|c|c|c|c|}
\hline Pc & AVE & Significance number & Factor loading & Index sign & construct \\
\hline \multirow{4}{*}{0.823859} & \multirow{4}{*}{0.539845} & 17.87613 & 0.787587 & $\mathrm{q} 1$ & \multirow{4}{*}{ Brand experience } \\
\hline & & 9.448065 & 0.673714 & $\mathrm{q} 2$ & \\
\hline & & 13.75081 & 0.719173 & q3 & \\
\hline & & 11.95152 & 0.753649 & $q 4$ & \\
\hline \multirow{3}{*}{0.784251} & \multirow{3}{*}{0.547946} & 15.41149 & 0.760278 & q5 & \multirow{3}{*}{ Satisfaction with brand } \\
\hline & & 11.39975 & 0.731536 & $q 6$ & \\
\hline & & 12.30525 & 0.728471 & $\mathrm{q} 7$ & \\
\hline \multirow{3}{*}{0.808915} & \multirow{3}{*}{0.585598} & 11.70296 & 0.723928 & Q8 & \multirow{3}{*}{ Trust in brand } \\
\hline & & 16.44126 & 0.781604 & Q9 & \\
\hline & & 21.2205 & 0.788554 & $\mathrm{q} 10$ & \\
\hline \multirow{4}{*}{0.860756} & \multirow{4}{*}{0.607222} & 14.21222 & 0.758388 & q11 & \multirow{4}{*}{ Pleasure with brand purchase } \\
\hline & & 16.01447 & 0.77224 & q12 & \\
\hline & & 18.04397 & 0.789668 & q13 & \\
\hline & & 21.0745 & 0.796117 & q14 & \\
\hline \multirow{5}{*}{0.810351} & \multirow{5}{*}{0.461103} & 10.92977 & 0.668351 & q15 & \multirow{5}{*}{ Brand sign value } \\
\hline & & 8.438682 & 0.655866 & q16 & \\
\hline & & 10.25386 & 0.690703 & q17 & \\
\hline & & 7.836449 & 0.658483 & q18 & \\
\hline & & 12.35267 & 0.719715 & $q 19$ & \\
\hline \multirow{6}{*}{0.893864} & \multirow{6}{*}{0.584580} & 14.04479 & 0.758038 & Q20 & \multirow{6}{*}{ Loyalty to brand } \\
\hline & & 18.70929 & 0.789718 & Q21 & \\
\hline & & 23.43758 & 0.834492 & Q22 & \\
\hline & & 12.85262 & 0.727642 & Q23 & \\
\hline & & 13.32709 & 0.723825 & Q24 & \\
\hline & & 15.61416 & 0.74796 & $\mathrm{q} 25$ & \\
\hline
\end{tabular}

Considering table 4, significance values of all indices have t values above 1.96 therefore these indices are appropriate factor loadings for measuring dimensions studied in the research. Further, AVE values and composite reliability are in allowable range.

\subsection{Inner model}

After testing the outer model, it is necessary to investigate the inner model which indicates relationships among latent variables of the research. Using the inner model, we can investigate research hypotheses. The tested conceptual model has been shown in figure 2. The numbers written on the lines indicate Beta coefficnets resulted from regression equation which are the very path coeffiencts. The numbers inside each circle indicate R-squared values the predicting variables of which have been connected to them via arrows.

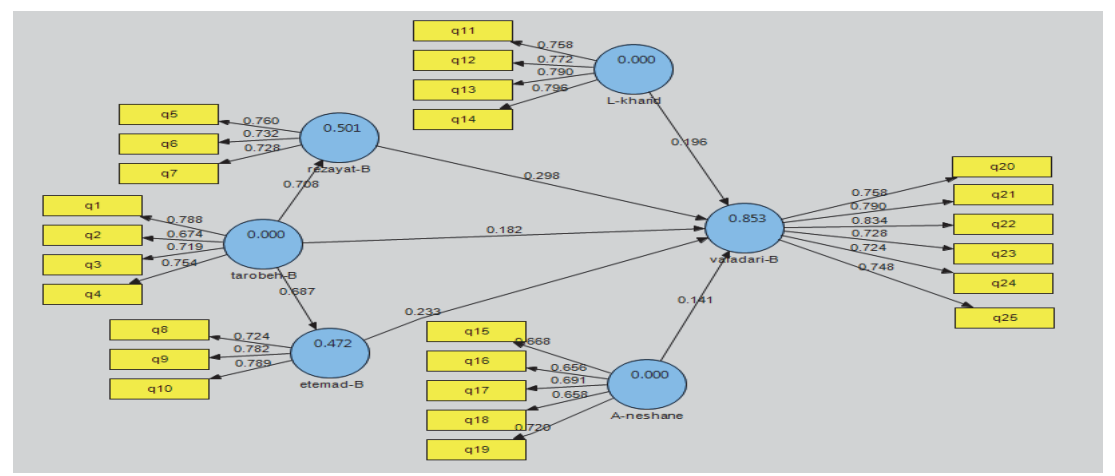

Figure 2. research tested model in Smart-PLS software

Standard beta values and also significance numbers for relationships among variables have been demonstrated in table 5 . 
Table 5. beta values and significance values for inner model

\begin{tabular}{|l|c|c|c|}
\hline Relationships between variables & Factor loading & T value & conclusion \\
\hline Brand experience---- loyalty to brand & 0.182 & 2.104874 & supported \\
\hline ----satisfaction with brand---Brand experience & 0.707957 & 13.283378 & supported \\
\hline ----trust in brandBrand experience & 0.686822 & 11.408804 & supported \\
\hline Satisfaction with brand ----loyalty to brand & 0.298135 & 3.835702 & supported \\
\hline Trust in brand ---- loyalty to brand & 0.233354 & 3.014116 & supported \\
\hline ----loyalty to brandpleasure with purchase & 0.196407 & 2.680056 & supported \\
\hline Brand sign value ----loyalty to brand & 0.141224 & 2.211265 & supported \\
\hline
\end{tabular}

Considering the fact that certainty level was assumed to be equal to 0.95 for testing research hypotheses, all hypotheses the significance numbers of which are out of +-1.96 range are supported. According to table 5 , all research hypotheses are supported in 95\% certainty level. In other words, all variables have significant impacts on loyalty to Apple Cellphones. Further, experience of using Apple Cellphones has a positive and direct impact on trust in brand and satisfaction with brand. R-Squared values indicate that totally $85.3 \%$ of changes in loyalty to Apple Company cellphones can be predicted by research variables. furthermore, $50.1 \%$ of variations in satisfaction with Apple brand and also $47.2 \%$ of variations in trust in Apple brand are predicted by experience of using Apple brand variable.

\section{Conclusion and Recommendations}

Brand loyalty acquisition and maintenance is an important challenge in today's competitive markets. many marketing researchers emphasize on the vital role of interaction between consumer and brands in customers' satisfaction, creation of favorable attitude towards a brand and improvement of link between customers and a brand. Loyalty to brand is followed by advantages like increasing sales and income, fighting against competitors, reduction in customer attraction costs and prevention from customers' sensitivity to competitors marketing actions. Brand loyalty creation involves investment in marketing programs and especially potential customers.

Today, fierce competitive among companies and challenge of attracting new customers and maintaining present customers and making them loyal to products involves companies looking for factors affecting customers' loyalty and conduction of necessary strategies. The present research investigated these factors using variables like brand experience, satisfaction with brand, trust in brand, pleasure with brand purchase and brand sign value and loyalty to brand. In fact, the research aimed to investigate factors which affect loyalty to Apple Company cellphones brand in Tehran City.

Results of the first hypothesis test showed that brand experience has a positive and significant impact on loyalty to brand. Loyalty to brand is defined as tendency to repeat purchases from a particular product with a particular brand out of several similar brands. Results showed that brand use experience has the greatest impact on loyalty to brand with a total influence of 0.55 (direct and indirect).

Results of the second hypothesis test showed that brand experience has a positive and significant impact on satisfaction with brand. Customers' satisfaction is the result of experience of a product or service and is affected by a product's performance. This result conforms to the results of studies conducted by Haw and Preks (2005), Zarantello and Smith (2010), Sahin et al (2011), and Walter et al (2013).

Results of the third hypothesis test showed that brand experience has a positive and significant impact on trust in brand. If use of a brand satisfies consumers, they trust in their future purchases in the brand. This result matches the result of studies conducted by Haw and Preks (2005) and Sahin et al (2011).

Results of investigation of the fourth hypothesis revealed that satisfaction with brand has a positive and significant impact on loyalty to brand. In fact, results showed that satisfaction with brand has a positive and significant impact on loyalty to brand. In fact, results showed that satisfaction with a brand (factor loading=29.8) has the greatest direct impact on loyalty to brand.

Results of the fourth hypothesis test showed that trust in brand has a positive and significant impact on loyalty to brand. This research showed that after satisfaction with brand, trust in brand has the greatest direct impact on loyalty to brand.

Results of the sixth hypothesis test showed that pleasure with brand purchase has a positive and significant impact on loyalty to brand. In fact, results showed that pleasure with brand purchase has the greatest impact on loyalty to brand after brand expeience, trust in brand and satisfaction with brand. 
Results of the seventh hypothesis showed that brand sign value has a positive and significant impact on loyalty to brand. It must be mentioned that results indicate that brand value has a factor loading equal to 1401 and has the least impact on loyalty to brand.

Finally, it can be concluded that brand has a direct impact on customers' satisfaction. Since a brand is a promise we give to our customers. Customers will be satisfied if we fulfill our promise. In fact, the influence of brand oncutomers' loyalty is directly resulted from their satisfaction. This shows that brand and satisfaction influence on loyalty. Lyalty is in fact a kind of psychological belonging and tendency to relationship withcompany. Further, brand results in continuous commitment in customers.therefore, if we are able to design a brand well and attract customers' attention we will be able to guarantee their loyalty to our products. This means long-term relationship between customers and company and longterm profitability.

\section{References}

Ashley, C. \& Leonard, H. A. (2009). "Betrayed by the Buzz? Covert content and consumer-brand relationships", Journal of Public Policy and Marketing, 28 (2), pp. 212-220.

Atilgan, E., Aksoy, S. \&Akinic, S. (2005),"Peter Minats of the Brand Equity: A VerifiCationApprouch in the Beverage Industry in Turkey", Journal of Marketing Intelligence \& Planning, Vol. 23, No. 2/3, PP. 237- 48.

BameniMoghaddam, M., Heidarzadeh, K. and Mehrzadi, H. (2011). "investigation of the importance of brand special name in achieving loyal customers for Iranian beverage and food machinery producers", journal of management studies, number 88, pp: 23-38.

Bin Ismail, H., Talukder,D., Panni, FK, (2006), "The Influence of Product Involvement on Brand Loyaltyln Malaysia", Proccedeings of Academy of Marketing Studies, 7-9.

Chaudhuri, A., Holbrook, M.B., (2002), "Product-Class Effects on Brand Commitment and Brand Outcomes: The Role of Brand Trust and Brand Effect", Journal of Brand Management, 10, 1; ABI/INFORM Global pg. 33- 58.

Coomber, s., (2002), "Branding, capstone", publishing oxford.

Datta, P. R. (2003)," The Determinants of Brand Loyalty", Journal of Media Academy of Business, 3(1/2), 138- 145.

DehghaniSoltani, M., Mohamamdi, A., Pour Ashraf, Y. and SayehMiri K. (2013). "investigation of factors which affect evaluation of consumers' attitude to brand development", journal of business management, series 5, number 1, pp: 85-104.

Haghighi, Mohammad; Dorosti, Ali; Rahnama, Afshin; Hoseinpour, Ali;(2012). 'Evaluation of factors affecting customer loyalty in the restaurant industry' African Journal of Business Management Vol. 6(14), pp. 5039-5046.

HeidarzadehHanzaee, Kambiz; Khoshpanjeh, Mahsa\&Rahnama, Afshin; "Evaluation of the effects of product involvement facets on brand loyalty" African Journal of Business Management Vol. 5(16), pp. 6964-6971, 18 August, 2011.

Hess, Jeff and Story, John, 2005,"Trust-based commitment: multidimensional consumer-brand relationships", Journal of Consumer Marketing,22/6, 313-322

Kapferer, J.-N. and Laurent, G. (1985a), "Consumer involvement profiles: a new practical approach to consumer involvement", Journal of Advertising Research, Vol.25 No.6, pp.48-56.

Kapferer, John Noel, 2006, "strategic management of brand", translated by SinaGhorbanlou, Moballeghan publications, first printing.

Kotler, Philip, 2006, "Kotler in marketing management: analysis, planning, implementation and control", translated by BahmanForouzandeh, Amoukhteh publications, third printing.

Laaksonen P., (1997), "Consumer Involvement: Concepts and Research". Routledge: London, UK.

O'Sullivan, D. \&McCallig, J. (2012). "Customer satisfaction, earnings and firm value", European Journal of Marketing, 46 (6), pp. $827-843$.

MotahhariNejad, F, Samadi, S, Toulabi, Z. and Pour AshrafY. (2014). "investigation of relationship between brand and consumer", journal of marketing management, number 23, pp: 127-147.

Mowen, John and Michael Minor, 2009, "consumer behavior", translated by KambizHeidarzadeh, center for scientific publications of Islamic Azad University, first printing.

Quester, P., Lim, Ai Lin,(2003)," Product Involvement /Brand Loyalty:Is There A Link? ",Journal of Product \& Brand Management, Vol.12 No, 23-29.

Rahnama, Afshin; Alaei, Abbas; Shafaee, Javad; Ariana, Ali;(2012) "Evaluation of Relationship Marketing Dimension Effect on Degree of Customer's Loyalty of Insurance Industry in Iran" Journal of Basic and Applied Scientific Research, 2(2)1842-1848

Rahnama, Afshin; Alaei, Abbas; Shafaee, Javad; Hamdam, Hadi;(2012) "Evaluating the Impact of Banking Services Quality on Customer Loyalty in Mellat Bank Ardebil Province" Journal of Basic and Applied Scientific Research, 2(3)2498-2506.

Sahin, A., Zehir, C. \&Kitapci, H. (2011). "The effects of brand experience, trust and satisfaction on the building brand loyalty: An empirical research on global brands", Procedia Social and Behavioral Sciences, 24, pp. 1288-1301.

Schmitt, B.H. (2009). "The concept of brand experience", Journal of Brand Management, 16 (7), pp. 417-419.

Shamim, A. \& Butt, M. M. (2013). "A critical model of brand experience consequences", Asia PasificJournal of Marketing and Logistics, 25 (1), pp. $102-117$

Uncles, D, M, Dowling, R, G, Hammond, K., (2003),"Customer Loyalty and Customer Loyalty Programs", Jurnal of CunsumerMarketing, Vol., 20 No. 4, pp. 294- 316.

Walter, N., Cleff, T. \& Chu, G. (2013). "Brand experiences influence on customer satisfaction and loyalty: A mirage in marketing research?", International Journal of Management Research and Business Strategy, 2 (1), pp. 130-144.

Yap, W. B., Ramayah, T. \&Shahidan, W. N. (2012). "Satisfaction and trust on customer loyalty: A PLS approach", Business Strategy Series, 13 (4), pp. 154-167.

Zarantonello, L. \& Schmitt, B. H. (2010). "Using the brand experience scale to profile consumers and predict consumer behavior", Journal of Brand Management, 17 (7), pp. 532-40. 